\title{
GLASS IN EARLY ISLAMIC SOCIETY - TOWARD A GREATER UNDERSTANDING
}

\author{
Patricia L. BAKER
}

\begin{abstract}
Our knowledge of glass production in the Mediaeval Islamic Middle East has been augmented by recent archaeological excavations in the region, although we still await the publication of a number of reports, describing in detail the significant vessels and furnace finds. This article suggests that investigation of the early and mediaeval literary sources from the Arab world could also lead us to a greater appreciation of how glass was valued and appreciated in those times, and of what qualities were deemed more aesthetically important by the purchases and collector. Yet these very qualities were for some reason set aside by the fourteenth century, when highly decorated enamelled and gilded work on poor quality glass had become the fashion at the Mamluk court.
\end{abstract}

Keywords: Islam, glass, Middle East, Mediaeval, literature

Archaeological excavations in the Middle East, especially work undertaken since the 1930s, have increased our awareness and knowledge of glass production in the lands of Eastern Mediterranean during the early Islamic period, while scientific analyses carried out in more recent times have alerted scholars and students alike to the exciting possibility of isolating certain regional productions. That said, we are still waiting for some nine reports of important archaeological excavations and surveys concerning early to mediaeval Islamic sites in Iran alone, to be published (Kröger 1995, 2-7) and probably this number would be tripled if similar excavation sites in Syria and Egypt were included. ${ }^{1}$ Furthermore a number of commentators have noted that, in archaeological reports concerning Islamic sites, glass finds are less likely to receive such intensive study as given to ceramic finds. As Salam-Liebich $(1978,138)$ ruefully remarked "Glass from excavations [of Islamic sites] is not always kept, and when kept it usually makes its way to museum basements, where it is lost, forgotten, and seldom published." Less than a decade ago James Allan (1995, vii) gave expression to a sense of frustration, felt by many colleagues, at the 
scarcity of reliable information regarding glass finds "Where stratigraphy has been recorded, as at Siraf [south-west coast of Iran], the lack of publication of the excavated material is tragic, if not a disgrace." 2

While we await these delayed publications, perhaps it is opportune to explore another avenues, such as the role of glass in early Islamic society. Investigation of the chronicles, geographies, scientific works and other documentary evidence from the period shed light on how glass was perceived in contemporary society and culture and such ideas were to remain influential in later centuries.

Glass shards, both architectural and vessel, have been found during excavations of some five of the seventeen so-called Umayyad desert palaces, ${ }^{3}$ but unfortunately little information has been published. ${ }^{4}$ Often the locations of these palace-compounds are in region historically associated with glass production but conversely in some cases, for example Qașr al-Hayr al-Sharqi located near Palmyra, east-northeast of Damascus, glass production in the immediate region has never been recorded so in such cases glass would have been transported to the site. It is logical to assume that the Umayyad political leadership wished to incorporate such decoration and artefacts within its walls that conveyed to the observer notions of status, power, prosperity and magnificence, and that included not only intricate plaster work, wall-paintings, but also mosaics and window glass. But was it simply that the rulers wished the observers to note and marvel at such lavish architectural decoration usually found in the main rooms often designated by the archaeologists as "audiencehalls" or the bath-house, or did they wish it to evoke other connections?

The early Islamic Arabic commentaries resonate with stories of the Qur'anic prophets, and one in particular was closely associated with majesty, super-human intelligence, and justice; this was Sulaymān (the Biblical Solomon), who could understand the languages of animals and birds, who was told news by the winds, who knew the hundredth name of Allah, who possessed a magic mirror which reflected all the cities of the world, etc. (EI ${ }^{2}$ q.v. "Sulaymān b. Dāwūd"). Like the legendary Iranian ruler, Jamshīd, who was credited with the invention of building construction, weapon and textile production, Sulaymān was associated with magnificent "palaces" such as the Roman Temple of Jupiter complex at Baalbek, Lebanon, commonly understood to have been constructed for his Egyptian consort. Both men were understood to be closely linked with Achaemenid Persepolis and Pasargadae, ${ }^{5}$ and with less palatial constructions - but nevertheless very important to the community bath-houses (Soucek 1975, 257; Dow 1996, 114). According to al-Tabarī (d. 923 
A.D.), one of early Islam's most important and influential Arab commentators, Jamshīd was said to have ordered the making of a glass chariot which, pulled by demons, rode across the skies (Rosenthal 1981, 350) while Solomon possessed "one thousand houses of glass on a wooden [carpet], in which there were three hundred wives and seven hundred concubines transported on the wind" (Brinner 1991, 154). However, one story is particularly relevant in the context of architectural glass in Umayyad palaces: the arrival of Balqīs (also spelt Bilqīs), the queen of Sheba, at the court of Solomon. Al-Tabari explained that one of these glass palaces was constructed with the express purpose of deterring Solomon from any thought of an alliance with Balqie, explaining the jinns and demons "were convinced that if only he could see for himself the hirsute growth on her legs, he would abandon any idea of making her his consort... [so] They built him a castle of green glass, making floor tiles [tawābiq] of glass that resembled water" (Brinner 1991, 162; see also Qur'an XXVII, 44). When she entered for an audience with Solomon, thinking the floor was water, she lifted her robes, revealing her hairy legs. Despite a sense of shock, Solomon was charmed by her conversation and determined she should be his queen. He commanded his courtiers to find a solution and so the first depilatory paste was invented (Brinner 1991, 163). This was a well-known embellishment to the Qur'anic description, probably first set down in Arabic in the Islamic world as early as the late seventh century A.D. by Wahb b. Munabbih (d. 727 or 732 A.D.) in his Kitāb al-tījān (Soucek 1993, 111), who described the depilatory paste as being made from lime collected from bath-house pipes (Soucek 1993, 115). The story was repeated in tales associated with the early prophets of Islam (Thackston 1978, 316-17) and later illustrated in certain manuscripts (e.g. 1552 Majālis al- 'ushshāq by Sulțān Ḥusayn Mīrzā, Persian ms. Ousley Add. 24, fol. 127b, Bodleian Library, Oxford). ${ }^{6}$

Such stories endured for centuries, whether in sixteenth-century Istanbul where Sultan Süleyman the Magnificent (r. 1520-66) was referred to as "the [new] Solomon of the Age" or Süleymān-i Zamān (Necipoğlu-Kafadar 1985, 100-01, see also 103-04), or in nineteenth-century Iran where Fath 'Alī Shāh (r. 1797-1834) would formally stand holding a golden staff surmounted by a figure of a hoopoe bird, so associating himself with both the Prophet Mūsā (Biblical Moses) and Solomon respectively. Even the ladies of the royal harem were not adverse to drawing comparisons with Solomon and more particular with Balqis as shown by İsmihan Sultan, the daughter of the Ottoman sultan Selim II (r. 1566-74), who took her bath in her glass-paned garden pavilion in Üsküdar, Istanbul (Necipoǧlu 1997, 40). 
Such stories could simply be dismissed as myth and fantasy but the published reports on the so-called desert palaces of the Umayyad period, when these give the locations of the architectural glass finds, note that shards of coloured and sometimes cold-painted window glass, featured in the large assembly rooms designated as "audience halls," as at Qașr al-Ḥayr al-Sharqi (Salam-Liebich 1978), or in the bath-house complex as at Khirbat al-Mafjar (Hamilton 1959; Brosh 1990). The last complex is located not far from Tiberias, whose bath-house had been long associated with Solomon (Dow 1996, 114), an intriguing connection especially when it is remembered that some modern scholars suggest the early building work relating to the bath-house at Khirbat alMafjar was undertaken during the reign of the Umayyad caliph, Sulaymān b. 'Abd al-Malik (r. 715-17), who could have been eager to promote connotations with such a fabulous ruler and prophet. ${ }^{7}$ Again the installation of such window glass in plaster grilles could be a mere architectural conceit but if it is taken into context with the finds from Qașr al-Hayr al-Sharqī, another possibility arises. Apart from the numerous window glass shards in various colours excavated from this Qașr al-Hayr complex build around 728-9 A.D., a distinctive kind of glass floor "tile" was found which parallels similar glass finds from the 1952 Raqqa excavations, discovered in the "audience hall" of the Abbasid caliph, alMu'tașim (r. 833-42 A.D.). These fragments are made of transparent colourless glass with a very slight green or turquoise tinge, as displayed in Damascus National Museum's Raqqa Room $^{8}$ and presumably were made in the same way as mosaic cube manufacture, that is by pouring hot glass into an iron mould containing rows of small square indentations. ${ }^{9}$ According to Salam-Liebich $(1978,144)$ and Abdul-Hak $(1960,141)$ the remains of plaster on the relief surface showed that it was this relief face that pressed into wet plaster, so that a smooth glassy floor surface was presented to the observer. Surely this association with Solomon and his court, and so with majesty and justice, was deliberate on the part of the patron, mason or decorator. It is tempting to suggest a similar explanation lies behind the finds of small lozenge, circular and "cartouche" pieces of glass and mother-of-pearl, thought to have formed a wall or floor panel, found in the mid-ninth-century Abbasid royal complex of Jawsaq al-Khaqāni in Sāmarrā, Iraq. ${ }^{10}$ In this palace were also found several pieces of glass millifiori tiles for use on floors or, more probably given their undamaged surface, for wall panels; there are indications in the contemporary poetry that glass was indeed used on the walls, as al-Buhturī spoke of one palace "the glass walls of its interior/ As if its striped marks were streaks of rain clouds arrayed between clouds, dark and light" (Meisami 2001, 73). ${ }^{11}$ And a statement of the 
twelfth-century Jewish traveller, Benjamin of Tudela, speaks of a Damascus "astronomy" palace whose walls were clad with glass, perforated in places so allow the sun's rays to be admitted and thus the hour to be calculated on a dial (Signer, 1983, 90-91). ${ }^{12}$

There is no doubt that glass was considered in early mediaeval Islamic society as a luxury product. Umm Ḥākim, a favourite of caliph Hishām (r. 72443), owned a fabulous green glass drinking bowl, apparently round like a human skull, embellished with a gold handle, weighing eighty mithqāls (in total, or just the glass?), that is approximately the weight of eighty gold dinar coins ${ }^{13}$; this was obviously put on show occasionally as it formed the focus for several jokes told by his successor, Walid, to his courtiers. This object survived the fall of the Umayyad dynasty because it was recorded in the treasury of the Abbasid caliph Hārūn al-Rashīd (Hamilton 1988, 93-94). Glass sometimes formed an important part of diplomatic gifts from the caliph; among rich, luxurious textiles, rugs, manuscript and an onyx table, al-Ma'mūn (r. 813-17) sent an Indian ruler "a goblet (jām) of [Egyptian glass] zujāj fir'awnì one finger (iṣba) thick (ghilazahü), and one-and-a-half spans (shibr) wide (fathuhü), in the center of which, engraved in high relief (nābit), a representation (sürah) of a lion, faced by a kneeling man, who has inserted his arrow (sahm) in his bow (qaws) aiming towards the lion... taken from the treasury (khizānah) of Marwān b. Muhammad [d. 749]" (al-Qaddūmī 1996, 77, also 183).

So thickness of glass was obviously considered aesthetically pleasing. A victory banquet held to celebrate the taking of Aleppo in 1038 was celebrated with articles of rock crystal (billawr) and solid thick (muhkam) glass (alQaddūmī 1996, 132). ${ }^{14}$ Another piece was known as Qalb Salìm ("pure heart") owned by Abū al-Futūh Yūsuf, the important governor of Sicily during 989-98. Made as a blood-letting cup, it was small bowl, cut in high-relief with its two handles cut from the clear glass body, with "the name of Hārūn al-Rashīd [d. 809] and the year of manufacture ... inscribed in four lines on its edges (ḥ̂affâtihī)" (al-Qaddūmī 1996, 195-96). Al-Muqaddasī, writing 985-86, mentions muhkam as a speciality of Baghdad, while Ibn al-Faqīh notes this category of glass was usually made as goblets, skull-shaped bowls, cups etc. (Lamm 1941, 15). It would seem zujāj fir 'awnī (lit. Pharaonic, thus Egyptian glass) was cast glass, perhaps with a slight yellowish tinge whereas muhkam referred to a specific kind of clear thick glass, not necessarily cast (Lamm ibid.).

And it is apparent that the fire-polish of glass was also considered visually attractive because a number of shiny, "glazed" fabrics were described in twelfthcentury Egyptian documents as being like glass or (rock-) crystal (Goitein 1999, 
IV-174). Thick, "pure" (presumably without any colour impurities, seeds or cords) glass was highly prized as we have seen but at the same time thinness, translucency and fragility of glass were also admired. Abū Manșūr Muhammad b. Aḥmad al-Daqiqii of Ṭūs, living in the second half of the tenth century, compared a glass vessel to ice and water in its clarity and brilliance, and arguably its "whiteness" (Rice 1958). The advantages of using glass over pottery and gold vessels were a subject of discussion, as related by the Arab commentator al-Jāhiz (d. c.868-69): two misers from the eastern regions of Iran discussed the merits of glass, one stating "Glass is better than any other material; it is non-porous and non-absorbent, and does not collect dust ... Glass ... withstands water and wine better than pure gold [vessels]" and "moreover it is manufactured, whereas gold is in its natural state ... glass is superior by virtue of its cleanness. Finally, glass is transparent, while gold is opaque ... When a ray of light strikes the glass, the flame and the lamp together become a single source of light, reflecting each other's rays ... its brightness is doubled, and if it shines in someone's eye it dazzles and may even blind him" (McNeill \& Waldman 1973, 125-26). And of course there is the well-known Qur'anic "Nūr" verse (sürah XXIV: 35) which compares a candle flame burning brightly in a glass lamp to the message of the Qur'an.

This "Nūr" verse and the popular belief that the Prophet Muhammad and his descendants, through the line of 'Alī and Fătima, possessed an aura of divine light (Flood 1999) ensured that translucency and brilliance of glass remained the most important aesthetic criteria of "good" glass in the mediaeval Islamic Middle East. Such "spiritual" light was considered divinely beneficial and it is known that many mediaeval pilgrims to the Christian sties in the Levant had similar beliefs as, when visiting the holy sites, they wore small glass mirrors set in plaster around their neck in order to "capture" the blessed light thought to radiate from holy relics (Flood 1999, 325). Translucency and the absence of any colour impurities were also prerequisites for glass produced for medical usage, especially those used for visual diagnoses of urine samples and for measuring units of "cupped" blood, although the cups themselves were often crudely made of thick, deeply coloured glass. ${ }^{15}$ Such practices continued for centuries as proved by the late-eighteenth-century Egyptian historian, al-Jabartī (d. 1825), who employed a glass analogy to argue the usefulness of history: "If this age should urinate in a bottle, time's physician would know its ailment" (Philipp \& Perlemann 1994, I-6).

The absence of impurities was also important in the manufacture of spectacles. It appears that Venetian glassmakers produced glass lens for 
spectacles from the end of the thirteenth century (Ashtor 1992, VII-503) and, bearing in mind that Islamic optical science was more advanced than that of Europe until the sixteenth century or later, presumably the advantages of convex glass lens (over those of rock crystal) were known in the mediaeval Middle East. Eyeglasses are mentioned by Muslim poets from the beginning of the sixteenth century. Qāsim-i Kāhī suggested for the devout Muslim "the heart's eyeglasses lie in the mirror of the knee"; in other words it is by sitting in meditation, that one's soul is illuminated with self-knowledge. Another, Kalim, compared the narcissus flower in early morning as wearing the eyeglasses of dew (Schimmel 1992, 296). However, the first unambiguous documentary reference of spectacles as distinct from (crystal) lenses in the Islamic world I have found so far is dated 3 March 1620, when the Carmelite priest, Father Thaddeus was asked by the Safavid shah of Iran, 'Abbās I (r. 1587-1629), to lend him his spectacles "with the attachments that fasten them to the ears ... saying he wanted to see whether that invention suited him too ... The Father wished to hand over the spectacle-case, too, so that the spectacles might the better be protected against being broken. But the Shah said that there was no need - he should not be afraid." It is to be hoped that he was correct in that promise (HC 1939, I-246). One of the earliest illustrations of glasses is the portrait of Mìr Musavvir offering a petition drawn and painted by his son, Mīr Sayyid 'Alī, circa 1565 (inv. No. 3.6191, b, Musée Guimet, Paris). ${ }^{16}$

Transparency and clarity logically lead to associations with honesty and truthfulness, qualities easily broken and damaged by adverse actions. Al-Ṭabarì notes a report that the Sasanian shah, Khusraw II (d. 628) was pressed to submit (to the inevitable truth of Islam?) by an angel of God, bearing two glass bottles which were shattered on his refusal, so foretelling the end of the Sasanian dynasty in Iran (Bosworth 1999, 337). Centuries later these qualities were still recognized in certain nineteenth-century Arabic proverbs, such as: "The world is a mirror: show thyself in it, and it will reflect thy image" (i.e. it is best to be honest) or "A dirty liquor in a wretched bottle," a description of a bad character of ill-kept appearance (Burckhardt 1972, 149).

The fragility of glass was recognised by the Persian poet, Jāmī (d. 1492) who pleaded in a couplet "Don't throw the stone of injury on the heart of the poor; this glass can be broken easily, but it is difficult to repair" (Schimmel 1992 , n. 35 on 439) and indeed, because a bride's contribution to the new household had to be returned intact to her and her family if the marriage was dissolved, glass rarely formed part of her trousseau in Fatimid Egypt (Goitein 1999, IV-106). Often within the private household, glass vessels were kept in 
safety in the khizānah, a locked cupboard, the key to which was held only by the man of the house and handed on the death-bed to his heir (Goitein 1999, IV131). Deliberately breaking glass was therefore seen as profligate, reprehensible behaviour as seen in a story of al-Tanūkhī (d. 994), in which a man, eager to dispose of his last five thousand dinars, acted on the advice of a companion by purchasing cut glass with all but five hundred dinars which he then spent on women, food and drink for a party. Two mice and a cat were then deliberately let loose among the glass with the inevitable result. The guests grabbed the fragments and "made a broken bottle into a cup, and a broken cup into a pomade jar, and pasted up what was cracked; these they sold amongst themselves, making up a goodly number of dirhems" (McNeill \& Waldman 1973, 103). This implies that even broken expensive glass had a certain second-hand value, perhaps in the same way as chipped and repaired eighteenth-century European glass has today for some collectors.

Glassmaking was an obvious sign of a sophisticated culture and society, one that was not based purely on agriculture and animal husbandry, according to the renowned philosopher and historian, Ibn Khaldūn (d. 1406): "Activities required for luxury customs and conditions exist only in cities of a highly developed culture ... Among such activities are those of glassblowers, goldsmiths, perfumers, cooks, coppersmiths, biscuit makers, ... weavers of brocades, and the like ... Such crafts will exist in a particular city but not in others" (Rosenthal 1967, II-302).

Goitein's researches into the Geniza documents found in a Jewish synagogue, Cairo, and generally dated 1016-1240, indicate that there were other comparable links between these crafts, as well as merchants dealing in glass often also dealt in other expensive, luxurious goods, such as patterned silks and coral. Like gold- and silversmiths and dyers, glass-workers entered into contractual arrangements with each other. A contact dated 1057 signed by two Jewish glassmaking partners stipulated the hiring of another glassmaker for a year to work on the furnace, at a day rate of five dirhams plus one dirham for lunch; a penalty of five gold dinars was to be paid to two synagogues if the work was not done. This day rate was higher than the usual labourer's wage so it would appear this man was taken on to repair or rebuild the furnace, rather than just feed it. Working at the furnace was recognised as hard physical labour undertaken in unpleasant conditions ${ }^{17}$ because those glassmakers who contributed more money or materials to the venture, worked less on the shopfloor: a 1134 Cairo contract stipulated that the partner who loaned ten dinars and materials worth twice that amount to his partner, worked two days a week for 
over six months against the four days a week of the other. These Jewish documents also prove that Muslims and Christians worked in glass, sometimes sharing the facilities with others of different faiths; the famous Maimodides ruled that it was lawful that a Muslim and a Jewish glass maker, working alongside each other, to divide the profits so those accruing to Friday production, when the Muslim absented himself from work, went to the Jewish glassmaker, and vice versa on profits from the Saturday working (Rosenthal 1999, II-78, 110, 296, 306, V-169). Another indication of the hardship faced by the glassmaker as distinct from the cutter and decorator, working dway from the furnace, may be seen in the rates of pay of an Iraqi glasscutter (kharrāz) about a century earlier; he was paid only one and one-third dirhams or one and a half dirhams a day (Margoliouth 1992, 147). Glasscutters could be employed by the early-tenth-century Abbasid palace as mentioned by al-Hilāl al-Ṣābi' (d. 1056), working alongside carpenters and papermakers etc. (Serjeant 1972, 20).

The documentary evidence reveals that during the eighth to eleventh centuries A.D. glass production was comparatively specialist with some thirteen types of manufacture recognised by different terminology (as distinct to seventeen in pottery), with some glassworks known for the manufacture of window-glass, or lamps, or drinking glasses, or bottles and flasks, or beads whether it was eighth-century Basra or fifteenth-century Egypt (Shatzmiller 1994, 201, see also 224-26). In sixteenth-century Ottoman Istanbul, glass engravers, painters, gilders and metal-foil decorators were recognised for their individual skills (Rogers 1983, 255). Despite the cultural standing of glass, and the public acknowledgement of the skills required and the harsh working conditions, comparatively few pieces of Islamic glass have survived marked with the maker's name. Mayer in 1954 (1954, 262-65) managed to find only seven names, including the maker or decorator of a fourteenth-century Mamluk mosque lamp and Sarhos Ibrahim, the designer of the sixteenth-century stainedglass windows in the Süleymaniye Mosque, Istanbul. Four years later, another name was added by Storm Rice $(1958,8-16)$ from a moulded glass vessel, which allowed workshop identification of another four similar pieces and a Toledo glass which "possibly" gave the place of manufacture as Baghdad: "the only known Islamic glass with indication of its provenance epigraphically recorded ..." Since then, a few others are now known including one naming "“Uthmān b. Abū Nașr, the glassmaker" scratched into the external wall of a brass dip mould, and another on a lustre- or stained-painted glass identifying the maker or decorator as Sunbāt and the production place as Damascus (Carboni 2001, 85 and 209). ${ }^{18}$ 
Syrian glass was acknowledged as the finest in the mediaeval period. Tha' alibì (d. 1038) who spent most of his life living and working in the eastern regions of Iran noted that Syria was known for its delicious apples, fine olive oil and "Also, the thinness and translucence of Syrian glass are proverbially famous; one says 'more delicate than Syrian glass' or 'clearer than Syrian glass"' (Bosworth 1968, 118), with its major glassmaking workshops located in Tyre, Akka, Hebron, Tripoli, Armanaz, Antioch (today's Antakya) and Aleppo. That said, there was perceived or visually recognisable differences between the production of the various Syrian centres as a late-eighteenth-century Mughal poet, Āzād Bilgrāmī, alluding to the historic concept of the vault of the heavens, queried "in dealing with this old sky, does it matter / Whether it is of European, Aleppan or Syrian glass?" (Schimmel 1992, 278). Al-Qazvīnī (d. 1283) spoke of the wonderful glass on sale in a special section of Aleppo's bazaars and some fifty years later an Iranian geographer wrote "the best glass founders are those of Aleppo. The glass bottles from here are perfectly transparent and very famous" (Lamm 1941, 63).

All these Eastern Mediterranean towns were comparatively close to the rich source of soda, the Eastern Mediterranean plant, Haloxylon articulatum, also known as Hammada scoparia or Salsoda kali/soda. The late-tenth-century commentator, al-Muqaddasī, mentioned the profitable exporting of such plant ash ushnān from Aleppo, and a fourteenth-century author Șalāḥ al-Dīn Kutubì mentions ushnān mills in Damascus, but it was the Bavarian botanist, Leonhart Rauwolff, who in 1573 described this local Bedouin obtained kali by burning two types of plants (presumably, salsoda kali and salsoda soda) near the Tripoli coast to sell to keen Venetian customers (Ashtor 1992, 482, also 488, 494). This trade had had a long history, at least from 1296 if not earlier and although soda was available from the vase deposits in the Wādī Națūn region north of Cairo, that was considered very inferior in quality for the price to the Syrian stuff (Ashtor 1992, 507; see Jomard c.1815 for late-eighteenth-century Egyptian soda).

Of course this investigation is in the preliminary stages but it appears that the mediaeval Arabic literature, the work mainly of chroniclers, geographers, philosophers, commentators and poets, does not contain much specialist information about the daily manufacture of glass, or any other major craft. Such writers were more interested in other matters but also it is clear that those with a knowledge of glassmaking kept the secrets of the trade; al-Jāhiz tells of the ninth-century miser, Khālid b. Yazīd of Baghdad, being near to death, promised to reveal to his son certain important (and therefore financially rewarding) 
manufacturing secrets such as "the melting of marble, making of mosaic, recipes for the manufacture of ... swords, manufacture of fir 'awnī ['Pharaonic,' see above] glass and the process of sublimation in the way it should be done" (Serjeant 1997, 39).

Other glassmaking centres definitely existed; a major archaeological glassmaking site has been located close to the Sāmarrā palaces, and the north bank of the Iraqi Tigris known locally as ma'mal al-zujāz and awaits further investigation (Northedge 1986). During the last two decades a number of furnaces identified with glassmaking have been excavated in controlled archaeological investigation. In Solkhat in the Crimea (Kramarovsky 1998, 99), Bahnasā, middle Egypt (Baker, forthcoming), Raqqa, northern Syria (Henderson 1999) the remains of circular-walled furnaces were found, and this "beehive" form is so strongly associated with the South Mediterranean glassmaking tradition that one European scholar has interpreted the Ottoman 1583 Surname manuscript illustration (ms. H. 1344 fol. 33, Topkapı Sarayı Museum, Istanbul) showing such a glass furnace as indisputable evidence of Venetian domination over sixteenth-century Turkish glass manufacture. However, the rectangular ground plan was also used for some mediaeval Islamic glass furnaces, in which the annealing chamber was located to one side of the main furnace rather than over it as in the "beehive" model. Such furnaces have been found in Akka (late thirteenth century), Israel (Weinberg 1987) and is still the model for several latetwentieth-century workshops in Cairo (Henein \& Gout 1974), Syria (Imam 1964; Gaulmier 1937, 53-59), Iran (Wulff 1966, 69-70) and Afghanistan (Reut 1973, 97-111).

Glassmaking continued for centuries and indeed Arwanaz is still a centre of domestic glass production in Syria. However, but by the eighteenth century as already noted by European travellers in Iran, the quality of the glass was low with bubbles and debris. During his travels, Volney (1787, II-325) noted only one glassworks in operation, in Hebron; instead the soda was generally used for soap manufacture: "They have also some soap manufactories, the kali, for which is sold them by the Bedouins, and a very ancient glass-house, the only one in Syria. They make there a great quantity of coloured rings, bracelets for the wrists and legs, and for the arms above the elbow, besides a variety of other trinkets, which are sent even to Constantinople." The unsatisfactory quality of domestically-produced glass was also criticised by European travellers in Iran a century earlier, complaining of the "seeds," bubbles, striations and discolouring in the glass, blaming the excessive use of cullet, unsatisfactory fuel and discontinuous furnace firing (Charleston 1974) but modern enthusiasts of 
Islamic glass will recognise most if not all these faults as characteristics of fourteenth-century Mamluk enamelled glass of Egypt and Syria, so avidly sought by Western collectors from the late nineteenth century. As yet we do not know whether the fashion for such highly decorated glass in fourteenth-century Egypt and Syria was customer-led as a reaction against "traditional" glass values or promoted by the glassmaker to disguise falling standards in batch-production.

\section{Notes}

1 Since Kröger's 1995 publication, the final report of Ghubayrā, including a short section with drawings and illustrations of some of the glass finds, has been published; see Baker 2000 .

2 A number of preliminary reports concerning the Sirāf excavations was published in the British academic journal Iran, but detailed information regarding the glass finds and the discoveries of the glass workshops is still unpublished.

3 Other than the five excavated sites, five others are said to be too ruined to yield useful results, while 'Ammān and 'Anjar are viewed as problematic in the eyes of Grabar 1993, 93.

4 It is known that architectural glass from an Umayyad context was found at Qașr al-Hayr al-Gharbì, and at Raqqa, in a ninth-century context; however very few details have been published; see Lafond 1968, Abdul-Hak 1960.

5 Both Persepolis and Baalbek were described as mal'ab Sulaymān (Solomon's resort); Soucek 1975, 256; for further associations with Solomon in Iranian classical literature, see Melikian-Chirvani 1971; and in Ottoman literature, see Necipoğlu-Kafadar 1985.

6 A fuller description is to be the subject of this author's paper at the September 2003 Congress of the International Association for the History of Glass, London, and subsequent publication of the Annales.

7 It should be noted that Walid also associated with the building referred to himself as the son of David, that is Solomon; Soucek 1993, 119.

8 An illustration of this "tile" fragment was published in Joundi 1975, 175 and fig. 79, and Catalogue 1976, fig. 79.

9 Such moulds are still in operation in the 1980s, as seen by the author at the Whitefriars glassworks, Middlesex, U.K. The ceramic fragment with glass adhering to two of its surfaces, identified as "mosaic" by Henderson 1996, 212, is a piece from a furnace pot still holding glass residue.

10 Lamm 1928, 109 no. 309. Soucek 1976, 85-86 and 95-99 suggests that the early Islamic mosaic decoration of the Dome of the Rock, Jerusalem, would have been associated in the ninthcentury Islamic mind with stories of Solomon beautifying his Temple there with gold and jewels.

11 It is thought the gold-"sandwich" glass tiles (e.g. Corning Museum of Glass, New York state, inv. No. 54.1.82), generally taken to be of Syrian or Iraqi manufacture, variously dated circa ninth-eleventh century, were also made as wall tiles.

12 The text is ambiguous: immediately before this short statement, Benjamin of Tudela was describing the Great Umayyad Mosque in Damascus but it is unlikely he was thinking of that particular mosque as a glass-clad palace. It is known that the streets around this complex were closely associated with glassmaking by the early fourteenth century.

13 The exact weight of the mithqāl is not known but appears to have been closely related to the weight of the contemporary dinar; $E I^{2}$ q.v. "dinar."

14 Al-Qaddūmi 1996, para. 126, n. 4, 314-15 suggests such a muḥkam glass vessel might have been similar in appearance to the so-called Hedwig glasses, cut in high relief; however, there is little archaeological evidence from the Islamic Middle East to support the earlier-held theory that the "Hedwig" glasses were made in the region. 
15 For an illustration of a cupper applying such a cup, see fourteenth-century Maqāmāt alHarīì (ms. 22114, fol. 51, the British Library, London).

16 The Iranian artist, Mīr Muṣavvir, and a colleague Sayyid Āqā Jalāl al-Dīn Mīrak alHasan̄i, are known to have designed a jām-khāna (mirror-house, or pavilion whose internal walls were covered with glass mirror-work) for the Safavid prince Bahrām, as recorded by Dust Muhammad in 1544; Binyon et al. 1933, 186. Other pre-eighteenth-century Islamic illustrations of people wearing glasses include: a portrait of "Fānī, the painter," Qazvin work of the Safavid period, 1580-90 (inv. no. 1948-12-11-011, the British Museum, London; and two portraits of Riżā-yi 'Abbāsī signed by Mu'īn-i Muṣavvir, Isfahan, 1673 (Princeton University Library, Garrett Collection and the other in a private collection).

17 See Evliya Ceelebi 1968, section XXXIII, 213 for comments on the seventeenth-century glass workshops near Eyüp and Hasköy, Istanbul: "Whoever wishes to see a specimen of the fire of hell, may look on the fire in these glass factories; but not withstanding its fury, it is but a spark in comparison of the fire of hell." Many Karaite Jewish families were resettled in Hasköy. After the 1660 fire in the Yeni Cami area, Golden Horn, destroyed their housing there.

18 Both items are now in the Corning Glass Museum, New York State, U.S.A.

\section{Bibliography}

Abdul-Hak, S. 1960: “Contribution à l'étude ...," Annales du ler congrès de l'Association internationale pour l'histoire du verre, Liège 1958, 79-96.

Allan, J. 1995: Foreword to Islamic Art in the Ashmolean Museum, Oxford Studies in Islamic Art no. X (i), Oxford.

Ashtor, E. 1992: "Levantine Alkali Ashes and European Industries," Technology, Industry and Trade ..., Croft Road, U.K., section VII, 478-522.

Baker, P. L. 2000: “The Glass Finds," in A. D. H. Bivar (ed.), Excavations at Ghubeyra, Iran, London, 197-233.

Baker, P. L. forthcoming: "Glass Finds at Bahnasa (working title)," in G. Fehervari (ed.), Final Report of the Bahnasa Excavations, Egypt (working title).

Binyon, L. et al. 1933: Persian Miniature Painting, London.

Bosworth, C. E. 1968: The Lata'if al-ma 'arif of Tha 'alibi, Edinburgh.

Bosworth, C. E. 1999: tr. and ed. al-Ṭabarī, Ta'rìkh al-rusul w'al-mulūk, vol. 5, "The Sasanids, the Byzantines ...," Albany.

Brinner, W. M. 1991: tr. and ed. al-Ṭabarī, Ta'rīkh al-rusul w'al-mulük, vol. 3, "Children of Israel," Albany.

Brosh, N. 1990: “Glass window fragments from Khirbet al-Mafjar," Annales du $11^{e}$ congrès de l'Association internationale pour l'histoire du verre, Basel 1988, Amsterdam, 247-56.

Burckhardt, J. L. 1972: Arabic Proverbs (first pub. 1830), London.

Carboni, S. 2001: Glass of the Sultans, New York.

Catalogue 1976: Catalogue (du) Musée national de Damas, Damascus.

Charleston, R. 1974: "Glass in Persia in the Safavid Period and Later," Art \& Archaeology Research Papers 5, 12-27.

Dow, M. 1996: The Islamic Baths of Palestine, Oxford.

EI²: Encyclopaedia of Islam, second edition, 11 vols., Leiden / London, 1960-2002.

Evliya Çelebi 1968: Narrative of Travels ... 1611-80, reprint, New York.

Flood, F. B. 1999: "Light in Stone," in J. Johns (ed.), Bayt al-Maqdis: Jerusalem and Early Islam, Oxford Studies in Islamic Art no. IX (ii), Oxford, 311-60.

Gaulmier, J. 1937: “Note sur la fabrication du verre à Armanaz,” Bulletin d'études orientales 6, 
53-59.

Goitein, S. D. 1999: A Mediterranean Society, 6 vols., paperback ed., Berkeley.

Grabar, O. et al. 1978: City in the Desert: Qasr al-Hayr East, 2 vols., Harvard Middle Eastern Monograph Series XXIII/XXIV, Cambridge, MA.

Grabar, O. 1993: "Umayyad Palaces Reconsidered," Ars Orientalis 23, 93-108.

Hamilton, R. W. 1959: Khirbat al-Mafjar: an Arabian Mansion in the Jordan Valley, Oxford.

Hamilton, R. W. 1988: Walid and his friends: an Umayyad tragedy, Oxford Studies in Islamic Art no. VI, Oxford.

H[enry] C[hick] 1939: A Chronicle of the Carmelites in Persia, 2 vols., London.

Henein, N. H. \& J. F. Gout 1974: Le verre soufflé en Egypte, Cairo.

Henderson, J. 1996: “Report on Raqqa archaeological excavation,” Levant 28, 212.

Henderson, J. 1999: "Archaeological and Scientific Evidence for the Production of Early Islamic Glass in al-Raqqa, Syria," Levant 31, 231-46.

Imam, C. 1964: "L'artisanat du verre en Syrie," Annales du $3^{e}$ congrès de l'Association internationale pour l'histoire du verre, Damas 1964, 184-90.

Joundi, A. 1976: Musée national de Damas: Département des antiquités syro-orientales, Damascus.

Jomard, E. F. c. 1809: “État moderne," Description d'Égypte, 2 vols., Paris.

Kramarovsky, M. 1998: "The import and manufacture of glass in the territories of the Golden Horde," in R. Ward (ed.), Gilded and Enamelled Glass from the Middle East, London.

Kröger, J. 1995: Nishapur: Glass of the Early Islamic Period, New York.

Lafond, J. 1968: "Découverte de vitraux historiés du Moyen-Âge à Constantinople," Cahiers archéologiques 18, 231-38.

Lamm, C. J. 1928: Das Glas von Samarra, Berlin.

Lamm, C. J. 1941: Oriental Glass of Mediaeval Date Found in Sweden and the Early History of Lustre-Painting, Stockholm.

McNeill, W. H. \& M. R. Waldman 1973: The Islamic World, New York.

Margoliouth, D. S. 1954: The Table-talk of a Mesopotamian Judge, London.

Mayer, L. A. 1954: "Islamic glassmakers and their works," Israel Exploration Journal 4, 262-65.

Melikian-Chirvani, A. S. 1971: "Le Royaume de Salomon: les inscriptions persanes de sites archéménides," Le monde iranien et l'Islam 1, 1-41.

Necipoǧlu-Kafadar, G. 1985: "The Süleymaniye Complex in Istanbul: An Interpretation," Muqarnas 3, 92-117.

Necipoğlu, G. 1997: "The suburban landscape of 16th century Istanbul as a mirror ...," in A. Petruccioli (ed.), Gardens in the time of the great Muslim Empires, Leiden, 32-37.

Northedge, A. \& R. Falkner 1987: “The 1986 Survey Season at Sammara," Iraq 49, 143-73 and plates.

Philipp, Th. \& M. Perlemann 1994: 'Abd al-Rahman al-Jabarti's "History of Egypt...," 4 vols., Stuttgart.

Al-Qaddūmī, Gh. H. 1996: tr. and ed., Book of Gifts and Rarities, Cambridge, M.A.

Reut, M. 1973: "Le verre soufflé de Herat," Studia Iranica 2, 97-111.

Rice, D. S. 1958: "Early Signed Islamic Glass," Journal of the Royal Asiatic Society [of Great Britain ...J, April, 8-16.

Rogers, J. M. 1983: “Glass in Ottoman Turkey,” Istanbuler Mitteilungen 33, 239-67.

Rosenthal, F. 1967: Ibn Khaldun: the Muqaddimah, an Introduction to History, Bollingen Series XLIII, New York. 


\section{GLASS IN EARLY ISLAMIC SOCIETY - TOWARD A GREATER UNDERSTANDING}

Rosenthal, F. 1981: tr. and ed. al-Tabarī, Ta'rīkh al-rusul w'al-mulūk, vol. 1, "General Introduction and From the Creation to the Flood," Albany.

Salam-Liebich, H. 1978: “Glass Finds,” in Grabar 1978, I, 138-47.

Schimmel, A. 1992: A Two-Colored Brocade, Chapel Hill.

Scott-Meisami, J. 2001: "The Palace-Complex as Emblem: Some Samarran Qasidas," in C. F. Robinson (ed.), A Medieval Islamic City Reconsidered, Oxford Studies in Islamic Art, no. XIV, 69-78.

Serjeant, R. B. 1972: Islamic Textiles: Material for a History up to the Mongol Conquest, Beirut.

Serjeant, R. B. 1997: tr. Abu 'Uthman ibn Bhar al-Jahiz: The Book of Misers, Reading, U.K.

Shatzmiller, M. 1994: Labour in the Medieval Islamic World, Leiden.

Signer, M. A. et al. 1980: The Itinerary of Benjamin of Tudela, Malibu.

Soucek, P. P. 1975: review of O. Grabar, The Formation of Islamic Art (1973) in Iranian Studies 8, 248-63.

Soucek, P. P. 1976: "The Temple of Solomon in Islamic Legend and Art," in J. Guttmann (ed.), The Temple of Solomon, Missoula, MT., 73-123.

Soucek, P. P. 1993: “Solomon's throne / Solomon's Bath: model or metaphor," Ars Orientalis 23, 109-34.

Thackston Jr., W. 1978: The Tales of the Prophet of a-Kisa'i, Boston.

Volney, C.-F. de 1787: Travels through Syria and Egypt in the years 1783, 1784, and 1785, 2 vols., London.

Weinberg, G. D. 1987: “A Glass Factory of Crusader Times in Northern Israel: a preliminary report," Annales du $10^{e}$ congrès de l'Association internationale pour l'histoire du verre, Madrid, Amsterdam, 305-16.

Wulff, H. E. 1966: The Traditional Crafts of Persia, Cambridge, MA. 